\title{
Article \\ Human Proximal Tubule Epithelial Cells (HK-2) as a Sensitive In Vitro System for Ochratoxin A Induced Oxidative Stress
}

\author{
Enrique García-Pérez ${ }^{1}$, Dojin Ryu ${ }^{2}$ (D) Hwa-Young Kim ${ }^{3}$, Hae Dun Kim ${ }^{2}$ and Hyun Jung Lee ${ }^{2, *(1)}$ \\ 1 School of Food Science, Washington State University, P.O. Box 646376, Pullman, \\ Washington, DC 99164-6376, USA; enrique.gape@gmail.com \\ 2 Department of Animal, Veterinary, and Food Sciences, University of Idaho, 875 Perimeter Drive MS 2330, \\ Moscow, ID 83844-2330, USA; dryu@uidaho.edu (D.R.); haedunk@uidaho.edu (H.D.K.) \\ 3 Department of Biochemistry and Molecular Biology, Yeungnam University College of Medicine, \\ Daegu 42415, Korea; hykim@ynu.ac.kr \\ * Correspondence: hlee@uidaho.edu; Tel.: +1-208-885-9703; Fax: +1-208-885-2567
}

Citation: García-Pérez, E.; Ryu, D.; Kim, H.-Y.; Kim, H.D.; Lee, H.J. Human Proximal Tubule Epithelial Cells (HK-2) as a Sensitive In Vitro System for Ochratoxin A Induced Oxidative Stress. Toxins 2021, 13, 787. https://doi.org/10.3390/ toxins 13110787

Received: 29 September 2021 Accepted: 4 November 2021 Published: 6 November 2021

Publisher's Note: MDPI stays neutral with regard to jurisdictional claims in published maps and institutional affiliations.

Copyright: (c) 2021 by the authors. Licensee MDPI, Basel, Switzerland. This article is an open access article distributed under the terms and conditions of the Creative Commons Attribution (CC BY) license (https:// creativecommons.org/licenses/by/ $4.0 /)$.

\begin{abstract}
Ochratoxin A (OTA) is a mycotoxin that is potentially carcinogenic to humans. Although its mechanism remains unclear, oxidative stress has been recognized as a plausible cause for the potent renal carcinogenicity observed in experimental animals. The effect of OTA on oxidative stress parameters in two cell lines of LLC-PK1 and HK-2 derived from the kidneys of pig and human, respectively, were investigated and compared. We found that the cytotoxicity of OTA on LLC-PK1 and HK-2 cells was dose- and time-dependent in both cell lines. Furthermore, increased intracellular reactive oxygen species (ROS) induced by OTA in both cell lines were observed in a time-dependent manner. Glutathione (GSH) was depleted by OTA at $>48 \mathrm{~h}$ in HK-2 but not in LLC-PK1 cells. While the mRNA levels of glucose-6-phosphate dehydrogenase (G6PD) and glutathione peroxidase 1 (GPX1) in LLC-PK1 were down-regulated by 0.67 - and 0.66 -fold, respectively, those of catalase (CAT), glutathione reductase (GSR), and superoxide dismutase 1 (SOD) in HK-2 were up-regulated by $2.20-, 2.24-$, and 2.75 -fold, respectively, after $72 \mathrm{~h}$ exposure to OTA. Based on these results, we conclude that HK-2 cells are more sensitive to OTA-mediated toxicity than LLC-PK1, and OTA can cause a significant oxidative stress in HK-2 as indicated by changes in the parameter evaluated.
\end{abstract}

Keywords: ochratoxin A (OTA); oxidative stress; renal carcinogen; kidney cell lines; LLC-PK1; HK-2

Key Contribution: The effect of OTA on oxidative stress in two kidney-derived cell lines was evaluated, and dose-, time-dependent effects on oxidative stress in both cell lines were observed. HK-2 cells are more sensitive to OTA-mediated toxicity than LLC-PK1.

\section{Introduction}

Ochratoxin A (OTA) is a potent mycotoxin that is a possible human carcinogen classified in Group 2B by the International Agency for Research on Cancer (IARC) [1]. Due to the different growth requirements of the fungal species that produce OTA in the genera of Aspergillus and Penicillium, OTA can be found in a wide variety of agricultural commodities and their processed products, including cereal grains, coffee, nuts, and wine [2-4]. While epidemiological data are lacking, the array of toxicities in animals associated with dietary exposure to OTA suggests OTA as a public health concern. OTA is well known for its kidney toxicity in different animal species, and it causes kidney tumors in rodents [5,6]. OTA is also known to be hepatotoxic, teratogenic, mutagenic, and immunosuppressive [7-9].

The exact mechanism of OTA toxicity or chemical carcinogenesis has not been elucidated yet. According to the proposed mechanisms related to OTA toxicity, acute and chronic toxicity of OTA are related directly or indirectly to (a) inhibition of mitochondrial respiration and ATP production [10,11]; (b) inhibition of protein synthesis [12,13]; (c) OTAinduced DNA damage [14,15]; (d) lipid peroxidation [16-18]; and (e) the production of 
reactive oxygen species (ROS) and resulting oxidative stress [19-21]. Based on the toxicological data available to date, oxidative stress appears to be the most plausible underlying mechanism of toxicity of OTA $[22,23]$. However, the involvement of oxidative stress in OTA-mediated toxicity remains debatable, and several reports concluded that oxidative stress does not play a pivotal part in OTA-mediated toxicity [24-26]. The occurrence of oxidative stress/damage is worth confirming, as several studies reported varying oxidative (DNA) damage in the kidney in vitro and in vivo [14,20,27-29].

OTA's half-life in animals and human is $77 \mathrm{~h}$ in young calves [30], $88.8 \mathrm{~h}$ in pigs, $8.2 \mathrm{~h}$ in rabbits, $4.1 \mathrm{~h}$ in chickens [31], and 35.6 days in humans [32]. More importantly, differences in the OTA serum/plasma half-life account for most of the high variability in OTA toxicity observed among different animal species. While pig is generally considered as being the most sensitive to OTA nephrotoxicity among animal species [33], it is unclear whether other species may be more sensitive, particularly in responding to OTA-induced oxidative stress. Thus, this study aimed to examine and compare OTA-mediated oxidative stress in two immortalized cell lines, i.e., the kidney proximal tubule epithelial cell lines derived from pig and human kidneys, LLC-PK1 and HK-2, respectively.

\section{Results}

\subsection{Effect of OTA on Cell Viability}

To determine the effect of OTA on cell viability, LLC-PK1 and HK-2 cells were treated with various concentrations of OTA, ranging from $1.95 \mathrm{nM}$ to $3 \mu \mathrm{M}$, for different time periods ( $24 \mathrm{~h}, 48 \mathrm{~h}$, and $72 \mathrm{~h}$ ). In both cell lines, OTA led to a dose- and time-dependent decrease in cell viability (Figure 1). After $24 \mathrm{~h}$ OTA exposure, statistically significant $(p<0.05)$ effects were noted at $1 \mu \mathrm{M}$ and $31.25 \mathrm{nM}$ for LLC-PK1 and HK-2, respectively. Based on the dose- and time-dependent cell viability curves, the $\mathrm{IC}_{50}$ values for each OTA exposure time on LLC-PK1 and HK-2 cells (Table 1) were calculated. The effect of OTA on cell viability under serum-free conditions was evaluated in this study, as OTA binds to albumin [34], and thus, the presence of serum in the culture medium has been shown to decrease OTA cytotoxicity in both LLC-PK1 and HK-2 cells [21,35-41].

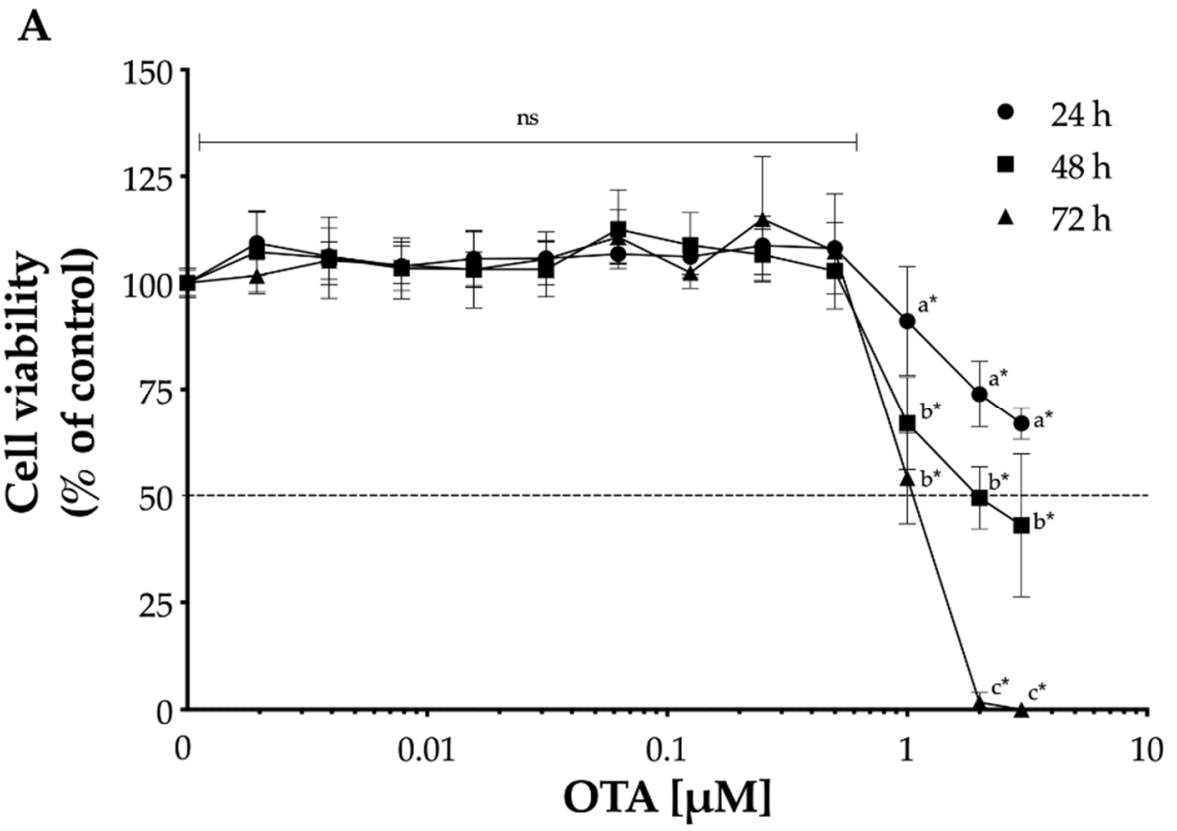

Figure 1. Cont. 


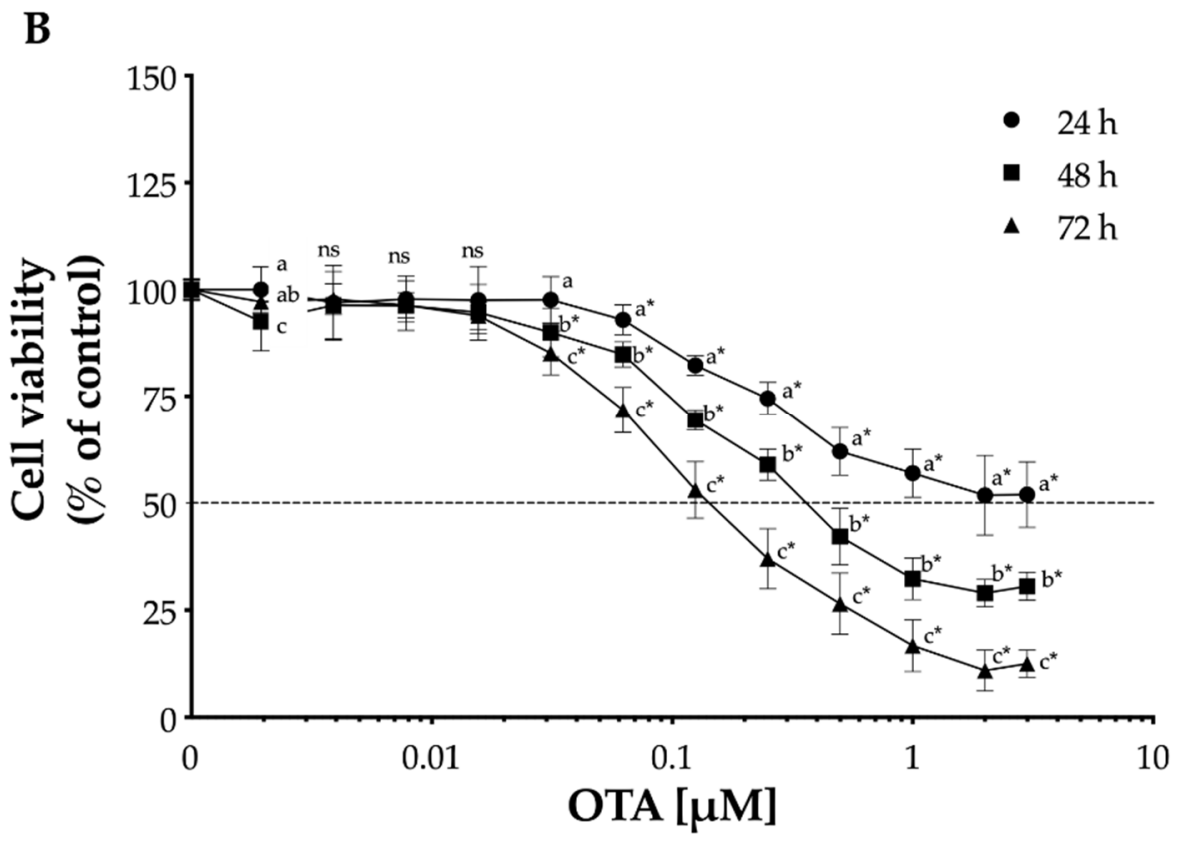

Figure 1. Time- and concentration-dependent cytotoxicity of ochratoxin A (OTA) in proximal tubule epithelial cells. Cell viability was determined by the reduction in MTT after incubation with OTA for $24 \mathrm{~h}(\bullet), 48 \mathrm{~h}(\boldsymbol{\square})$, and $72 \mathrm{~h}(\mathbf{\Delta})$ in LLC-PK1 $(\mathbf{A})$ and HK-2 $(\mathbf{B})$ cells. Values are mean $(n=3) \pm$ standard deviation, and they are expressed as percentage of control. The dotted line $(\cdots)$ represents the concentration of OTA that reduced the cell viability by $50 \%$. Different letters indicate a statistically significant difference $(p<0.05)$ between values within the same OTA concentration by Tukey's multiple comparison test, while ns = non-significant. Asterisks $\left({ }^{*}\right)$ indicate a statistically significant difference $(p<0.05)$ between values against each group control by Dunnett's test.

Table 1. Pig (LLC-PK1) and human (HK-2) proximal tubule epithelial cells.

\begin{tabular}{cccc}
\hline \multirow{2}{*}{ Cell line } & \multicolumn{3}{c}{ IC $_{\mathbf{5 0}}(\mu \mathrm{M}$ OTA $)$} \\
\cline { 2 - 4 } & $\mathbf{2 4} \mathbf{h}$ & $\mathbf{4 8 ~ h}$ & $\mathbf{7 2 ~ \mathbf { ~ }}$ \\
\hline LLC-PK1 & $>3$ & 2 & 1 \\
HK-2 & 2 & 0.382 & 0.125 \\
\hline
\end{tabular}

\subsection{Effect of OTA on Cellular Redox State}

A plausible mechanism by which OTA exert its toxicity is through the development of oxidative stress. Thus, OTA-mediated ROS formation was investigated through the oxidation of carboxy- $\mathrm{H}_{2} \mathrm{DCF}$ (dichlorodihydrofluorescein) to DCF (dichlorofluorescein). Figure 2 shows that OTA induced ROS in a time-dependent manner and that the concentration of ROS formed was higher in HK-2 compared with that in LLC-PK1 cells. After OTA exposure in both cell lines, the first significant $(p<0.05)$ effect was noted at $48 \mathrm{~h}$ and $3 \mathrm{~h}$ for LLC-PK1 and HK-2, respectively. In LLC-PK1 cells, formation of ROS at an elevated level was observed after $24 \mathrm{~h}$ exposure, but the OTA concentrations evaluated were higher compared with the concentration used in our study $[21,42,43]$. On the other hand, higher concentration of OTA (up to $800 \mu \mathrm{M}$ ) in HK-2 cells has been shown to increase ROS by $20 \%$ above control, whereas $50 \mu \mathrm{M}$ OTA only increased ROS by $10 \%$ after $24 \mathrm{~h}$ exposure $[39,44]$. In contrast, these results indicate that $0.125 \mu \mathrm{M}$ OTA was able to increase ROS levels significantly $(p<0.05)$ by 3.8 -fold compared with control after $3 \mathrm{~h}$ OTA exposure. 
A

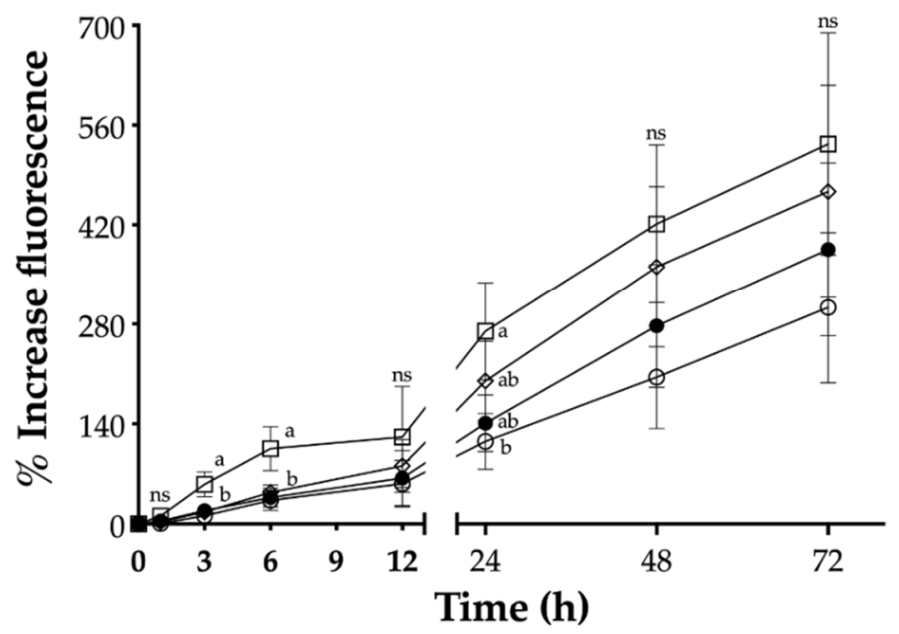

- Control

口 $\mathrm{H}_{2} \mathrm{O}_{2}(75 \mu \mathrm{M})$

$\diamond \operatorname{TBHP}(28 \mu \mathrm{M})$

- $\operatorname{OTA}(1 \mu \mathrm{M})$

B

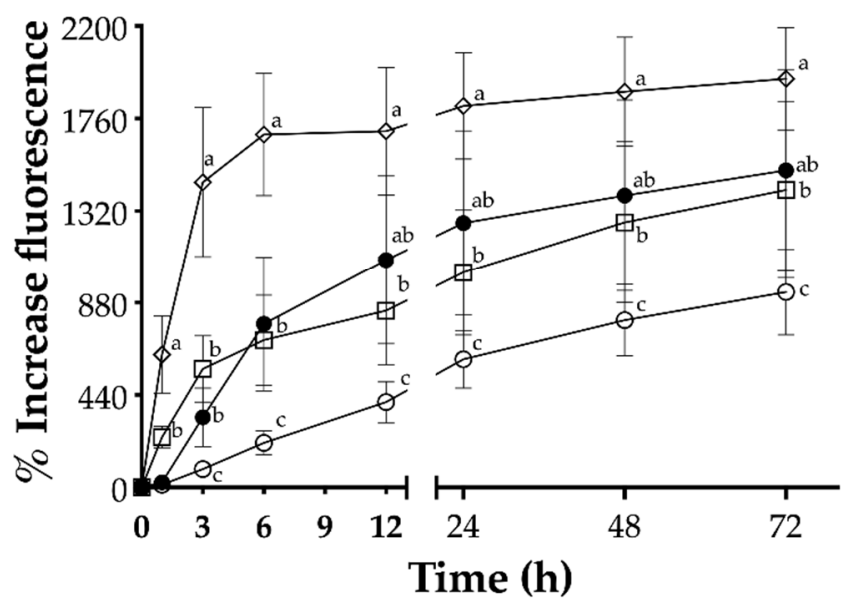

○ Control

口 $\mathrm{H}_{2} \mathrm{O}_{2}(2 \mathrm{mM})$

$\diamond \quad \operatorname{TBHP}(375 \mu \mathrm{M})$

- OTA $(0.125 \mu \mathrm{M})$

Figure 2. Production of reactive oxygen species by $\mathrm{H}_{2} \mathrm{O}_{2}, \mathrm{TBHP}$, and ochratoxin A (OTA) in proximal tubule epithelial cells at various exposure times up to $72 \mathrm{~h}$. Increase in DCF fluorescence, upon oxidation of carboxy- $\mathrm{H}_{2} \mathrm{DCF}$, was monitored after exposure to the test compound. (A) LLC-PK1 cells $\mathrm{H}_{2} \mathrm{O}_{2}(\square, 75 \mu \mathrm{M})$, TBHP $(\triangle, 28 \mu \mathrm{M})$, and OTA $(\bullet, 1 \mu \mathrm{M}) ;($ B $) \mathrm{HK}-2 \mathrm{H}_{2} \mathrm{O}_{2}(\square, 2 \mathrm{mM}), \operatorname{TBHP}(\triangle$, $375 \mu \mathrm{M})$, and OTA $(\bullet, 0.125 \mu \mathrm{M})$. In both cell lines, non-treated controls are denoted by open circles $(\bigcirc)$. Values are mean $(n=3) \pm$ standard deviation, and they are expressed as percentage increase in fluorescence from time zero. Different letters indicate a significant difference $(p<0.05)$ between treatments at each time by Tukey's multiple comparison test, while ns = non-significant difference.

\subsection{Effect of OTA on Intracellular GSH Levels}

Varying responses of the two cell lines to OTA were investigated by measuring intracellular GSH (reduced form) levels (Figure 3). In LLC-PK1 cells, a statistically significant $(p<0.05)$ reduction in GSH levels was observed only when the cells were exposed to either $\mathrm{H}_{2} \mathrm{O}_{2}$ and TBHP by $32 \%$ and $25 \%$, respectively, although OTA did not affect the levels of GSH at any time (Figure 3A). In contrast, HK-2 cells were affected only by $\mathrm{H}_{2} \mathrm{O}_{2}$ and OTA at $48 \mathrm{~h}$ and $72 \mathrm{~h}$, at which time GSH levels were reduced by $15 \%, 20 \%$, and $15 \%$, respectively (Figure 3B). 

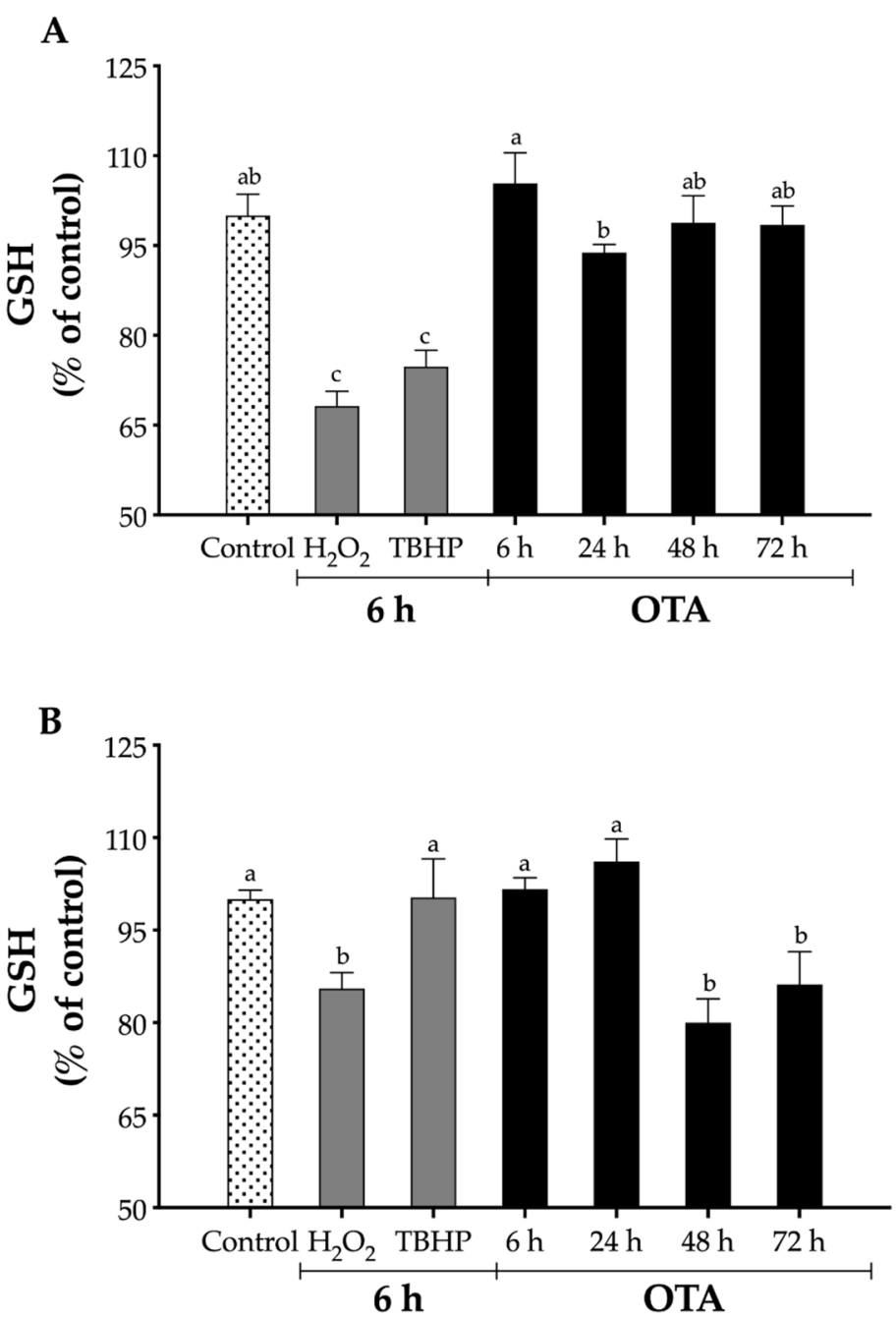

Figure 3. Relative levels of GSH in proximal tubule epithelial cells. GSH levels were determined by the reaction with DTBN to form 5'-thio-2-nitrobenzoic acid in cells homogenates. (A) LLC-PK1 cells $\mathrm{H}_{2} \mathrm{O}_{2}(75 \mu \mathrm{M})$, TBHP $(28 \mu \mathrm{M})$, and OTA $(1 \mu \mathrm{M}) ;(\mathbf{B}) \mathrm{HK}-2 \mathrm{H}_{2} \mathrm{O}_{2}(2000 \mu \mathrm{M})$, TBHP $(375 \mu \mathrm{M})$, and OTA $(0.125 \mu \mathrm{M})$. Values are mean $(n=3) \pm$ standard deviation, and they are expressed as percentage of control. Different letters indicate a statistically significant difference $(p<0.05)$ between treatments at each time by Tukey's multiple comparison test.

\subsection{Effect of OTA on Antioxidant Enzymes Gene Expression}

To further understand the differential involvement of OTA on oxidative stress in the two cell lines, responses to OTA were measured with the mRNA expression levels of CAT, G6PD, GPX1, GSR, and SOD1, which are key enzymes in the detoxification of ROS (Figure 4). The result was considered biologically meaningful when the mRNA levels changed $\geq 1.5$-fold that of control, either down- or up-regulated [45]. In LLC-PK1 cells, G6PD was down-regulated at $6 \mathrm{~h}$ and $72 \mathrm{~h}$ after OTA exposure (0.5- and 0.67-fold, respectively), while GPX was affected by OTA only after $72 \mathrm{~h}$ (0.66-fold) compared with control (Figure 4B-C). On the other hand, in HK-2 cells, only GPX was down-regulated at $72 \mathrm{~h}$ after OTA treatment (0.66-fold), whereas CAT, GSR, and SOD mRNA levels were up-regulated after $72 \mathrm{~h}$ incubation with OTA $(2.20-, 2.24-$, and 2.75-fold, respectively) compared with control (Figure 4A, 4D, 4E). The up-regulation of these genes is in line with our results showing an increase in ROS levels (Figure 2B) and a decrease in GSH levels (Figure 3B), as CAT and SOD neutralize $\mathrm{H}_{2} \mathrm{O}_{2}$ and $\mathrm{O}_{2} \bullet-$, respectively, while GSR reduced GSSG to maintain GSH. These antioxidant enzymes are known to be up-regulated during oxidative stress to counteract its toxic effects [46]. 

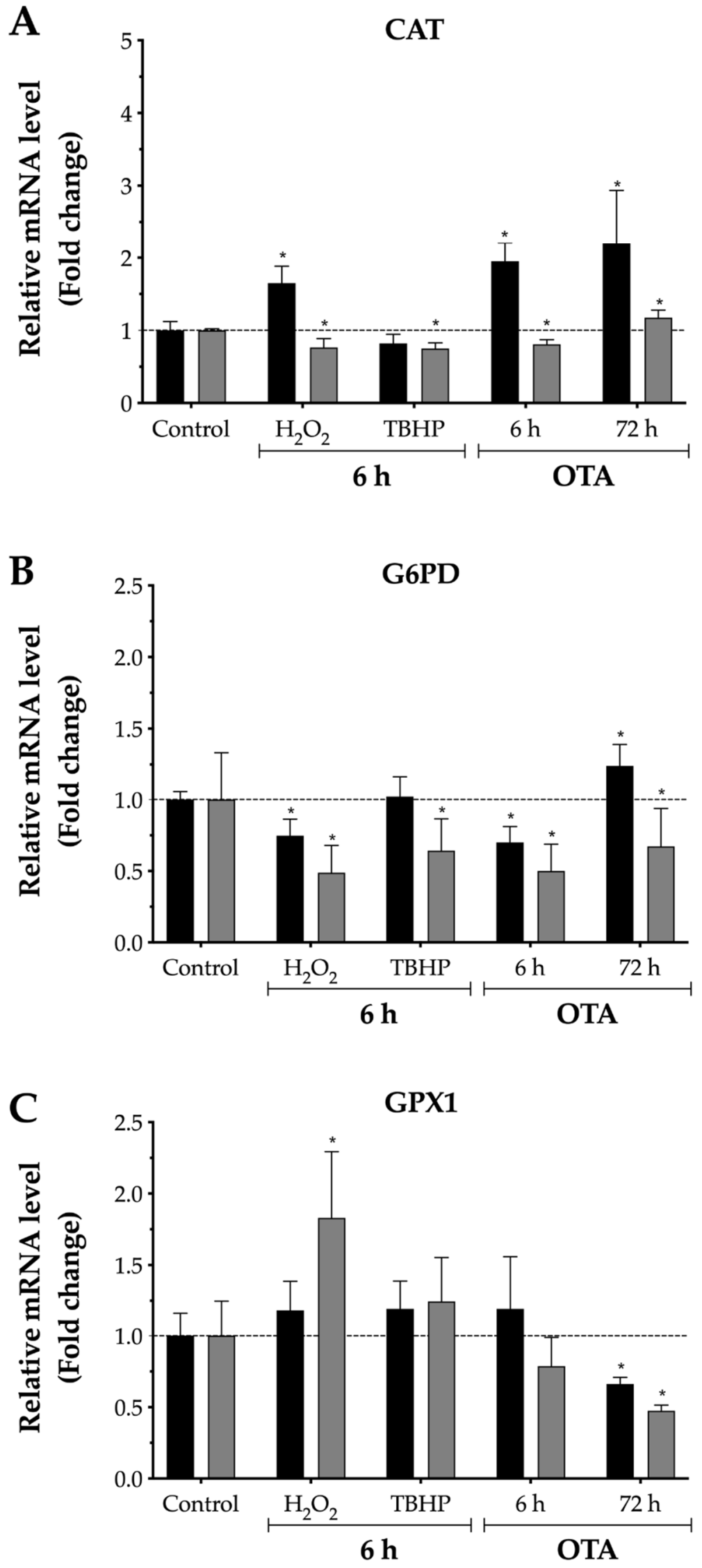

Figure 4. Cont. 

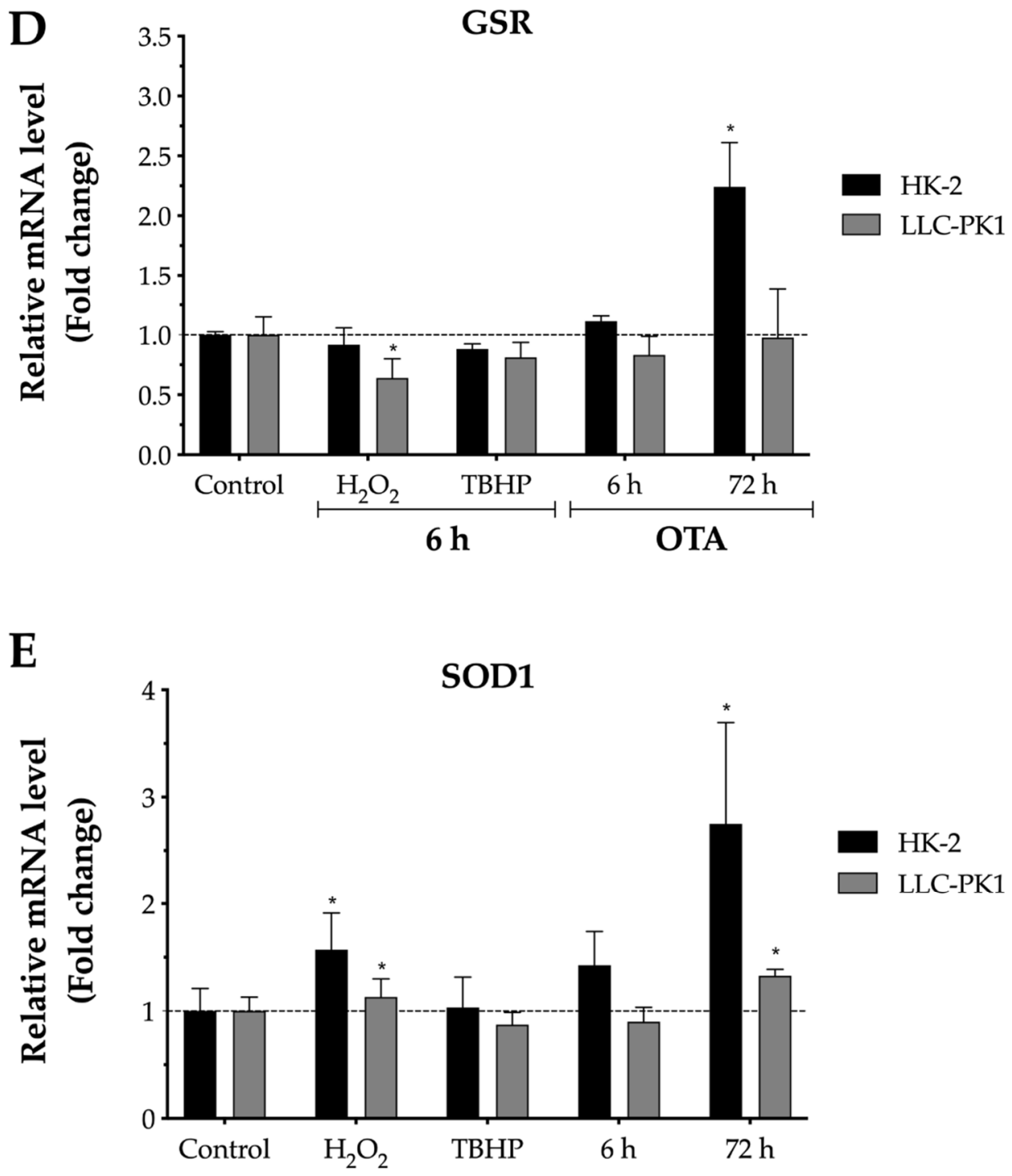

Figure 4. Relative mRNA levels of CAT, G6PD, GSR, GPX, and SOD in proximal tubule epithelial cells after exposure to $\mathrm{H}_{2} \mathrm{O}_{2}$, TBHP, and ochratoxin A (OTA). The mRNA expression of each gene was normalized using GADPH mRNA expression as housekeeping gene. LLC-PK1 cells $\mathrm{H}_{2} \mathrm{O}_{2}(75 \mu \mathrm{M})$, TBHP $(28 \mu \mathrm{M})$, and OTA $(1 \mu \mathrm{M})$. HK-2 $\mathrm{H}_{2} \mathrm{O}_{2}(2 \mathrm{mM})$, TBHP $(375 \mu \mathrm{M})$, and OTA $(0.125 \mu \mathrm{M})$. (A) Catalase, CAT. (B) Glucose-6-phosphate dehydrogenase, G6PD. (C) Glutathione peroxidase 1, GPX1. (D) Glutathione reductase, GSR. (E) Superoxide dismutase 1, SOD1. Values are mean $(n=3) \pm$ standard error of the mean, and they are expressed as fold change by the $2^{-\Delta \Delta \mathrm{Ct}}$ method. The dotted line $(\cdots)$ represents the level of mRNA for control cells. Asterisks $\left(^{*}\right)$ indicate a statistically significant difference $(p<0.05)$ between values against each cell line control by Student's $\mathrm{t}$-test. The fold change in OTA $72 \mathrm{~h}$ group was normalized with an independent control at $72 \mathrm{~h}$.

\section{Discussion}

The cytotoxicity of OTA on LLC-PK1 and HK-2 cells observed after 24 h exposure agreed with previous studies [35,39]. It is noteworthy to mention that the OTA concentrations did not exceed $3 \mu \mathrm{M}$, as OTA solubility in water at $25{ }^{\circ} \mathrm{C}$ has been reported to be between $1.05 \mu \mathrm{M}$ and $3.25 \mu \mathrm{M}[47,48]$. Under the conditions evaluated in this study, HK-2 cells were more sensitive to OTA-mediated cytotoxicity, as determined by the $\mathrm{IC}_{50}$ value (Table 1), which is consistent with other reports indicating differences in OTA-sensitivity among several species [38,49]. Jennings et al. [50] investigated the effect of OTA on three human renal proximal tubular models (HK-2, RPTEC/TERT1, and human primary cells), two rat renal proximal tubular models (NRK-52E and rat primary cells), and Wistar rat 
in vivo model. The study determined the largest differences between the human and rat cell culture models, while the results from human cell lines showed more similarity to the in vivo rat model because it is more likely that these differences are model-specific rather than species-specific per se [50]. The reason that human kidney cells are more sensitive to OTA toxicity may be explained by the differences in OTA uptake, differential OTA binding to intracellular proteins, and OTA elimination half-life. The $\mathrm{H}^{+}$-dipeptide cotransport is involved in the uptake of OTA in Madin-Darby canine kidney cells (MDCK), but it is not expressed in LLC-PK1 [51-53]; however, this transporter has not been studied in HK-2 cells. While LLC-PK1 is a spontaneously immortalized cell line, HK-2 is immortalized by transduction with human papilloma virus 16 (HPV-16) E6/E7 genes. The E6/E7 genes of HPV-16 have been reported to immortalize epithelial cells of diverse origin without significantly changing its phenotype or function [54-59]; however, most of immortalized cell lines have potentially limited their utility with derangements in cell function and structural integrity as a result of altered gene expression [60-63]. In addition, differences in OTA binding to intracellular proteins have been observed among several species, where human kidney homogenates showed a higher OTA protein binding than pig kidney homogenates [64-66]. This observation may also explain the differences in OTA-mediated cytotoxicity in this study, but these proteins have not been identified yet. Moreover, differences in elimination half-life of OTA varies greatly among species, e.g., $840 \mathrm{~h}$ in humans, $72-120 \mathrm{~h}$ in pigs, and 55-120 $\mathrm{h}$ in rodents, which may also influence the OTA-mediated toxicity in vitro $[31,32,67,68]$.

ROS, such as superoxide anion $(\mathrm{O} 2 \bullet-)$, hydroxyl radical $(\mathrm{OH} \bullet)$, and hydrogen peroxide $\left(\mathrm{H}_{2} \mathrm{O}_{2}\right)$ are produced during aerobic cellular metabolic processes. Although ROS play an important role in cell homeostasis, they can also promote the development of oxidative stress [69]. On one hand, ROS are required for the regulation of several physiological mechanisms, such as cell differentiation, cell proliferation, apoptosis, and regulation of redox sensitive signal transduction pathways [69]. At the same time, increased levels of ROS in the cell can also result in damage including cell death, mutations, chromosomal aberrations, and carcinogenesis [69]. Therefore, intracellular concentration of ROS is controlled by its production and/or removal by antioxidant systems. When the detoxifying mechanism fails, either by its inhibition or because it is not enough to counteract ROS levels, the cells undergo oxidative stress. It is important to mention that the oxidation of $\mathrm{H}_{2} \mathrm{DCF}$ to DCF is not specific for any particular ROS, and it also indicates the impact of $\mathrm{OH} \bullet$ formed during Fenton-type reactions between $\mathrm{H}_{2} \mathrm{O}_{2}$ and $\mathrm{Fe}^{2+}$ [70]. In addition, it has been observed that cytochrome $c$ is able to oxidize $\mathrm{H}_{2}$ DCF [70]. In line with this, OTA has been shown to induce apoptosis through caspase-3, in both human and pig renal cells, which is activated by cytochrome $c$ once released from the mitochondria upon mitochondrial membrane permeabilization [36,71-75]. Thus, OTA may be contributing to the increase in ROS formation via indirect mechanisms.

Oxidative stress produced by $\mathrm{H}_{2} \mathrm{O}_{2}$ and TBHP is well documented. The degree of ROS production by $\mathrm{H}_{2} \mathrm{O}_{2}$ and TBHP in LLC-PK1 and HK-2 by time was shown to be different in this study (Figure 2), due to their different mechanism in the body system. TBHP, which is a toxic compound, can cause extreme discomfort to body systems, including various organs, when it is exposed to cellular components by increasing membrane permeability along with hyperpolarization [76-78]. $t$-Butoxyl radicals that initiate lipid peroxidation are formed by reaction between TBHP and hemoglobin, and then extensive lipid peroxidative leads to membrane disturbance $[79,80]$. Therefore, cellular antioxidant systems such as GSH inhibit membrane disruption by scavenging the $t$-butoxyl radicals. $\mathrm{H}_{2} \mathrm{O}_{2}$, which is one of the major ROS, is known as an inducer necrosis-dependent on poly (ADP-ribose) polymerase-1 (PAPR-1), and a large amount of exogenous $\mathrm{H}_{2} \mathrm{O}_{2}$ causes oncotic death in cultured endothelial cells [81].

The active antioxidant system against ROS includes low molecular and high molecular mass antioxidants [46]. The most important endogenous antioxidant is GSH, as it is used to control ROS levels either directly (e.g., reaction with $\mathrm{O}_{2} \bullet-$ ), or serving as a cofactor for 
ROS-detoxifying enzymes (e.g., glutathione peroxidase). High molecular mass antioxidants include antioxidant enzymes, such as superoxide dismutase (SOD), catalase (CAT), and glutathione peroxidase (GPX). SOD converts $\mathrm{O}_{2} \bullet-$ to molecular oxygen $\left(\mathrm{O}_{2}\right)$ and $\mathrm{H}_{2} \mathrm{O}_{2}$, CAT converts $\mathrm{H}_{2} \mathrm{O}_{2}$ into oxygen and water, and GPX converts $\mathrm{H}_{2} \mathrm{O}_{2}$ into water [12]. In addition, GPX requires GSR and G6PD for its activity, which regenerates GSH and reduces nicotinamide adenine dinucleotide phosphate (NADPH) from its oxidized counterparts-glutathione disulfide (GSSG) and $\mathrm{NADP}^{+}$, respectively [46]. Endogenous antioxidants play an important role in neutralizing ROS, and among them, GSH is considered the most abundant molecule (1-10 mM) [82]. GSH can scavenge ROS either directly (e.g., reaction with $\mathrm{O}_{2} \bullet-$ ) or serving as a cofactor for ROS-detoxifying enzymes (e.g., glutathione peroxidase). While a significant $(p<0.05)$ reduction in GSH levels in LLC-PK1 cells was observed when cells were exposed to either $\mathrm{H}_{2} \mathrm{O}_{2}$ or TBHP, OTA did not affect the levels of GSH at any time (Figure 3A). This agrees with other studies in which OTA did not decrease the levels of GSH when up to $10 \mu \mathrm{M}$ OTA were tested in pig renal cells (LLC-PK1 and PK15 cells) after $24 \mathrm{~h}$ incubation $[21,83]$. Nonetheless, GSH depletion was observed when LLC-PK1 cells were exposed to $100 \mu \mathrm{M}$ OTA for $24 \mathrm{~h}$, which was concomitant with the high ROS level detected [21]. In contrast, $\mathrm{HK}-2$ cells were affected only by $\mathrm{H}_{2} \mathrm{O}_{2}$ and OTA at $48 \mathrm{~h}$ and $72 \mathrm{~h}$ (Figure 3B). It has been reported that OTA does not decrease GSH levels in human embryonic kidney cells (HEK293) after $24 \mathrm{~h}$ and $48 \mathrm{~h}$ incubation with OTA [84]. Thus, based on our results in HK-2 cells, the depletion of GSH is concomitant with the high levels of ROS observed (Figure 2B). To our knowledge, this is the first study conducted to evaluate the effect of OTA on GSH levels in HK-2 cells.

G6PD is an enzyme that maintains the levels of NADPH, which in turn promotes GSH regeneration; thereby, cells are protected against oxidative damage and injury [85]. Some G6PD transcription suppressors include cyclic adenosine monophosphate (cAMP) response element modulator (CREM), tumor necrosis factor alpha, and tumor suppressor p53 [86]. OTA has been shown to activate p53 in both monkey and human kidney cells, Vero and HEK293, respectively, and thus, the down-regulation of G6PD after OTA treatment in LLC-PK1 cells may be explained by the activation of p53 [87]. GPX1 is a selenium-dependent enzyme that utilizes GSH as a co-factor to detoxify $\mathrm{H}_{2} \mathrm{O}_{2}$ and other organic peroxides [46]. It is known that GPX1 activity and protein and mRNA levels decrease exponentially in progressive selenium deficiency. Recently, it was reported that the supplementation of selenomethionine alleviates OTA-induced toxicity in porcine renal (PK15) cells by enhancing GPX1 expression [88,89].

\section{Conclusions}

The most important finding of this study was that OTA induces different response in both porcine and human proximal tubule cells (LLC-PK1 and HK-2 cells, respectively). HK-2 cells at nanomolar OTA concentrations were more susceptible to OTA-mediated cytotoxicity than LLC-PK1 cells. Although some hypotheses have been proposed to explain the differences in cytotoxicity among several species, the exact mechanism is not well understood. In line with the decrease in cell viability, increased ROS levels as well as depletion of GSH in HK-2 cells were observed, while these effects were not observed in LLC-PK1 cells. Therefore, future work may attempt to understand whether OTA increases ROS levels by direct redox-cycling of OTA or by indirectly relocating lysosomal iron and/or mitochondrial cytochrome c. In addition, after $72 \mathrm{~h}$ OTA exposure, HK-2 cells up-regulated the transcription of CAT, GSR, and SOD, which are important antioxidant enzymes required for the detoxification of ROS and regeneration of GSH. G6PD and GPX mRNA levels in LLC-PK1 cells were the only genes affected after $72 \mathrm{~h}$ OTA treatment by down-regulating its transcription, which may indicate that longer OTA exposure time is required to observe an adverse effect in LLC-PK1 cells. Nonetheless, whether the downregulation of G6PD and GPX mRNA levels by OTA involved a direct mechanism, or whether they are being affected indirectly (e.g., tumor suppressor p53 and/or selenium deficiency) remains to be elucidated. In conclusion, the results presented in this study 
indicate that OTA, within its water solubility range, may be involved in the development of oxidative stress in HK-2 cells, as indicated by an increase in ROS levels, depletion of GSH, and increased sensitivity to cellular defense against oxidative stress, such as upregulation of CAT, GSR, and SOD1 mRNA levels. Based on the results, it is concluded that an immortalized proximal tubule epithelial cell line from normal adult human kidney (HK-2) can offer a sensitive in vitro system for studying OTA-induced oxidative stress, while pigs are known to be the most sensitive species to OTA. To the best of our knowledge, this is the first study demonstrating a differential response of two cell lines, LLC-PK1 and HK-2, toward OTA-mediated oxidative stress.

\section{Materials and Methods}

\subsection{Chemicals}

OTA, 3-(4,5-Dimethyl-2-thiazolyl)-2,5-diphenyl-2H-tetrazolium bromide (MTT), sodium dodecyl sulfate (SDS), $N, N$-dimethylformamide (DMF), reduced $L$-glutathione (GSH), tert-butyl hydroperoxide (TBHP), hydrogen peroxide $\left(\mathrm{H}_{2} \mathrm{O}_{2}\right)$, protease inhibitor cocktail, and 5,5'-dithio-bis(2-nitrobenzoic acid) (DTNB) were purchased from SigmaAldrich (St. Louis, MO, USA). Medium M199, keratinocyte-SFM $(1 \times)$ growth medium supplied with bovine pituitary extract and human recombinant epidermal growth factor, penicillin-streptomycin $(10,000 \mathrm{U} / \mathrm{mL}-10,000 \mu \mathrm{g} / \mathrm{mL}$ ), Dulbecco's phosphate buffer (no calcium and magnesium, DPBS), fetal bovine serum (FBS), $0.25 \%$ w/v trypsin $0.53 \mathrm{mM}$ EDTA, $0.05 \% w / v$ trypsin $0.53 \mathrm{mM}$ EDTA, 6-carboxy-2 ${ }^{\prime}, 7^{\prime}$-dichlorodihydrofluorescein diacetate (carboxy- $\mathrm{H}_{2}$ DCFDA), M-PER mammalian protein extraction reagent, Pierce bicinchoninic acid protein assay kit (BCA), TRIzol reagent, Quant-iT RiboGreen RNA assay kit, and high-capacity cDNA reverse transcription kit were obtained from Invitrogen (Waltham, MA, USA). RQ1 RNase-free DNase was obtained from Promega (Madison, WI, USA).

\subsection{Cell Culture}

Pig renal proximal tubular cell line (LLC-PK1) and human renal proximal tubular cell line (HK-2) were obtained from American Type Culture Collection (ATCC, Manassas, VA, USA) and were cultivated according to ATCC culture method recommendations. LLC-PK1 cells were cultured in M199 growth medium containing 1\% $v / v$ penicillin-streptomycin and $3 \%(v / v)$ FBS; HK-2 cells were cultured in keratinocyte-SFM growth medium supplemented with epidermal growth factor, bovine pituitary extract, and $1 \%(v / v)$ penicillin-streptomycin. All cells were maintained at $37{ }^{\circ} \mathrm{C}$ in a humidified atmosphere with $5 \% \mathrm{CO}_{2}$. All cells were seeded in each specific assay plate at a density of $3.13 \times 10^{4}$ cells $/ \mathrm{cm}^{2}$. OTA was dissolved in pure methanol $(24.76 \mathrm{mM})$ and further diluted in each cell growth medium under serum-free conditions; methanol concentration did not exceed $0.1 \%(v / v)$ in the final assay.

\subsection{Cell Viability Assay}

Cell viability was determined using the MTT assay, which is a widely accepted method for enumerating viable cells [90]. Briefly, cells were seeded in 96-well plate and allowed to grow for $24 \mathrm{~h}$ and were then treated with increasing concentrations of OTA (1.95 nM to $3 \mu \mathrm{M})$ in serum-free medium for different time intervals $(24 \mathrm{~h}, 48 \mathrm{~h}$, and $72 \mathrm{~h}$ ). After OTA exposure, MTT was added directly to the medium (final concentration of $0.5 \mathrm{mg} / \mathrm{mL}$ ), and the plate was incubated for $4 \mathrm{~h}$ at $37^{\circ} \mathrm{C}$. The formazan crystals formed were dissolved with $20 \%(w / v)$ SDS in DMF ( $\mathrm{pH} 4.7)$, and the absorbance was read at $570 \mathrm{~nm}$ on a Synergy 2 microplate reader (Biotek, Inc., Winooski, VT, USA). The cell viability was calculated with respect to non-treated cells as the control, and thus, the results are expressed as percentage of control. The percentage of cell viability was calculated by the following formula: $\%$ cell viability $=\left(\mathrm{Abs}_{\text {sample }}-\mathrm{Abs}_{\text {blank }}\right) /\left(\mathrm{Abs}_{\text {control }}-\mathrm{Abs}_{\text {blank }}\right) \times 100$, where Abs $=$ absorbance value. 


\subsection{Intracellular ROS Analysis}

The redox state of the cells was assessed using carboxy- $\mathrm{H}_{2}$ DCFDA conversion to fluorescent $2^{\prime}, 7^{\prime}$-dichlorofluorescein (DCF) [91]. Briefly, cells were seeded in black and clear bottom 96-well plate in growth medium and allowed to grow for $24 \mathrm{~h}$; then the medium was removed and cells washed with serum- and phenol red-free medium. Next, cells were incubated with $100 \mu \mathrm{M}$ carboxy- $\mathrm{H}_{2}$ DCFDA in serum- and phenol red-free medium for $30 \mathrm{~min}$ at $37^{\circ} \mathrm{C}$. Carboxy- $\mathrm{H}_{2}$ DCFDA was removed by washing the cells once with serum- and phenol red-free medium, and then exposed to OTA. The fluorescence of the cells from each well was measured and recorded during several time intervals in a Synergy 2 microplate reader. The excitation filter was set at $485 \pm 20 \mathrm{~nm}$, and the emission filter was set at $528 \pm 20 \mathrm{~nm}$. OTA concentrations were selected based on the $\mathrm{IC}_{50}$ value at $72 \mathrm{~h}$. Hydrogen peroxide and TBHP were used as positive control and their concentrations were selected based on each $\mathrm{IC}_{50}$ value at $6 \mathrm{~h}$ (data not shown). The results are expressed as the percentage increase in fluorescence and were calculated by the formula: $\left[\left(\mathrm{F}_{\mathrm{tf}}-\mathrm{F}_{\mathrm{t} 0}\right) / \mathrm{F}_{\mathrm{t} 0} \times\right.$ 100], where $\mathrm{F}_{\mathrm{tf}}=$ fluorescence at time $f \mathrm{~h}$, and $\mathrm{F}_{\mathrm{t} 0}=$ fluorescence at time $0 \mathrm{~h}$.

\subsection{Glutathione (GSH) Measurement}

Reduced glutathione was determined spectrophotometrically by quantifying the oxidation product (5'-thio-2-nitrobenzoic acid) upon the reaction between GSH and DNTB [92]. Briefly, cells were seeded in 6-well culture plates and allowed to grow for $24 \mathrm{~h}$, culture medium was removed, and then cells were exposed to OTA, $\mathrm{H}_{2} \mathrm{O}_{2}$, and TBHP as in Section 5.4. After each exposure time ( 6 h, 24 h, 48 h, or 72 h), medium was removed, and cells were lysed directly with M-PER supplemented with $1 \%(v / v)$ protease inhibitor cocktail according to manufacturer's instruction. Reduced glutathione concentrations were calculated based on a GSH standard curve using liner regression and were normalized to protein content determined by Pierce BCA protein assay. The results are expressed as percentage of control from each exposure time.

\subsection{Real-Time Quantitative Reverse Transcription PCR (RT-qPCR)}

All cells were seeded in a $100 \mathrm{~mm}$ culture dish (Corning, Oneonta, NY, USA) and allowed to grow for $24 \mathrm{~h}$ before treatment with OTA, $\mathrm{H}_{2} \mathrm{O}_{2}$, and TBHP as in Section 5.4. Cells were washed with DPBS, and RNA was extracted using the TRIzol reagent, following the manufacturer's instructions. Total RNA was quantified fluorometrically using the Quant-iT RiboGreen RNA assay kit according to the manufacturer's procedure. Genomic DNA was removed from $1 \mu \mathrm{g}$ of RNA using RQ1 RNase-free DNase according to the manufacturer's instructions. First-strand cDNA was synthesized from $1 \mu \mathrm{g}$ of RNA (gDNA-free) using a high-capacity cDNA reverse transcription kit according to manufacturer's procedure, and $10 \mathrm{ng}$ of cDNA for gene expression analysis was used. The PCR components mixes were then prepared by combining each cDNA sample with $20 \times$ TaqMan gene expression assay, $2 \times$ TaqMan gene expression master mix, and RNase-free water. Quantitative RT-PCR was done by the use of StepOnePlus Real-Time PCR System (Applied Biosystems, Waltham, MA, USA). Gene expression was quantified using the ${ }^{\Delta \Delta \mathrm{Ct}}$ method, and fold-change values are reported as $2^{-(\Delta \Delta \mathrm{Ct})}$ [93]. The TaqMan gene expression assays for LLC-PK1 cells used were SOD1 (Ss03375614_u1), CAT (Ss04323025_m1), GPX1 (Ss03383336_u1), GSR1 (AJRSADI), G6PD (AJS08JQ), and GAPDH (Ss03374854_g1). The TaqMan gene expression assays for HK-2 cells used were SOD1 (Hs00533490_m1), CAT (Hs00156308_m1), GPX1 (Hs00829989_gH), GSR (Hs00167317_m1), G6PD (Hs00166169_m1), and GAPDH (Hs99999905_m1). The relative amount of each target gene was normalized to GADPH.

\subsection{Statistical Analysis}

Statistical calculations were performed using the Statistical Package for Social Sciences version 23.0 (SPSS Inc., Chicago, IL, USA). The effect of different concentrations of OTA on individual parameters was analyzed by analysis of variance (ANOVA) and Dunnett's post hoc test, and comparisons of means was done with Tukey's post hoc test for 
multiple comparison, or with Student's $t$-test for two-group comparisons. Data represent means \pm standard deviation (SD) of three independent experiments of subsequent cell passages. Differences were accepted as statistically significant at $p<0.05$.

Author Contributions: Conceptualization, H.J.L.; methodology, H.J.L.; investigation, E.G.-P.; formal analysis, H.D.K.; resources, D.R.; writing—original draft preparation, E.G.-P.; writing-review and editing, H.J.L., H.-Y.K., H.D.K. and D.R.; visualization, E.G.-P.; supervision, H.J.L. and D.R.; project administration, H.J.L. and D.R.; funding acquisition, D.R. All authors have read and agreed to the published version of the manuscript.

Funding: This project was supported by the Agriculture and Food Research Initiative Competitive Grant, Agreement No. 2011-67005-20676, from the USDA National Institute of Food and Agriculture. E.G.-P. is supported by a PhD scholarship from CONACYT-Mexico (CVU 335085). This research was also partially supported by a Chung-Ang University research grant in 2020.

Institutional Review Board Statement: Not applicable.

Informed Consent Statement: Not applicable.

Data Availability Statement: The data presented in this study are available in article here.

Acknowledgments: This project was supported by Agriculture and Food Research Initiative Competitive Grant, Agreement No. 2011-67005-20676, from the USDA National Institute of Food and Agri-culture. E.G.-P. was supported by the PhD scholarship from CONACYT-Mexico (CVU 335085).

Conflicts of Interest: The authors have declared no conflicts of interest.

\section{References}

1. International Agency for Research on Cancer (IARC). Some Naturally Occurring Substances: Food Items and Constituents, Heterocyclic Aromatic Amines and Mycotoxins; IARC: Lyon, France, 1993.

2. Lee, H.J.; Ryu, D. Significance of ochratoxin A in breakfast cereals from the United States. J. Agric. Food Chem. 2015, 63, 9404-9409. [CrossRef] [PubMed]

3. Palumbo, J.D.; O'Keeffe, T.L.; Ho, Y.S.; Santillan, C.J. Occurrence of ochratoxin A contamination and detection of ochratoxigenic Aspergillus species in retail samples of dried fruits and nuts. J. Food Prot. 2015, 78, 836-842. [CrossRef]

4. Solfrizzo, M.; Panzarini, G.; Visconti, A. Determination of ochratoxin A in grapes, dried vine fruits, and winery byproducts by high-performance liquid chromatography with fluorometric detection (HPLC-FLD) and immunoaffinity cleanup. J. Agric. Food Chem. 2008, 56, 11081-11086. [CrossRef] [PubMed]

5. Pfohl-Leszkowicz, A.; Manderville, R.A. Ochratoxin A: An overview on toxicity and carcinogenicity in animals and humans. Mol. Nutr. Food Res. 2007, 51, 61-99. [CrossRef] [PubMed]

6. National Toxicology Program (NTP). Toxicology and carcinogenesis studies of ochratoxin A (CAS No. 303-47-9) in F344/N Rats (Gavage studies). Natl. Toxicol. Program Tech. Rep. Ser. 1989, 358, 1-146.

7. Schrenk, D.; Bodin, L.; Chipman, J.K.; del Mazo, J.; Grasl-Kraupp, B.; Hogstrand, C.; Hoogenboom, L.; Leblanc, J.C.; Nebbia, C.S. Risk assessment of ochratoxin A in food. EFSA Panel Contam. Food Chain. EFSA J. 2020, 18, e06113.

8. Lea, T.; Steien, K.; Størmer, F.C. Mechanism of ochratoxin A-induced immunosuppression. Mycopathologia 1989, 107, 153-159. [CrossRef]

9. Mayura, K.; Parker, R.; Berndt, W.; Phillips, T. Ochratoxin A-induced teratogenesis in rats: Partial protection by phenylalanine. Appl. Environ. Microbiol. 1984, 48, 1186-1188. [CrossRef] [PubMed]

10. Meisner, H.; Chan, S. Ochratoxin A, an inhibitor of mitochondrial transport systems. Biochemistry 1974, 13, 2795-2800. [CrossRef]

11. Wei, Y.; Lu, C.; Lin, T.; Wei, R. Effect of ochratoxin A on rat liver mitochondrial respiration and oxidative phosphorylation. Toxicology 1985, 36, 119-130. [CrossRef]

12. Creppy, E.; Kern, D.; Steyn, P.; Vleggaar, R.; Röschenthaler, R.; Dirheimer, G. Comparative study of the effect of ochratoxin A analogues on yeast aminoacyl-tRNA synthetases and on the growth and protein synthesis of hepatoma cells. Toxicol. Lett. 1983, 19, 217-224. [CrossRef]

13. Creppy, E.; Størmer, F.; Kern, D.; Röschenthaler, R.; Dirheimer, G. Effects of ochratoxin A metabolites on yeast phenylalanyl-tRNA synthetase and on the growth and in vivo protein synthesis of hepatoma cells. Chem. Biol. Interact. 1983, 47, 239-247. [CrossRef]

14. Kamp, H.G.; Eisenbrand, G.; Janzowski, C.; Kiossev, J.; Latendresse, J.R.; Schlatter, J.; Turesky, R.J. Ochratoxin A induces oxidative DNA damage in liver and kidney after oral dosing to rats. Mol. Nutr. Food Res. 2005, 49, 1160-1167. [CrossRef]

15. Mally, A.; Pepe, G.; Ravoori, S.; Fiore, M.; Gupta, R.C.; Dekant, W.; Mosesso, P. Ochratoxin A causes DNA damage and cytogenetic effects but no DNA adducts in rats. Chem. Res. Toxicol. 2005, 18, 1253-1261. [CrossRef]

16. Omar, R.F.; Hasinoff, B.B.; Mejilla, F.; Rahimtula, A.D. Mechanism of ochratoxin A stimulated lipid peroxidation. Biochem. Pharmacol. 1990, 40, 1183-1191. [CrossRef] 
17. Omar, R.F.; Rahimtula, A.D.; Bartsch, H. Role of cytochrome P-450 in ochratoxin a-stimulated lipid peroxidation. J. Biochem. Toxicol. 1991, 6, 203-209. [CrossRef]

18. Rahimtula, A.; Bereziat, J.; Bussacchini-Griot, V.; Bartsch, H. Lipid peroxidation as a possible cause of ochratoxin A toxicity. Biochem. Pharmacol. 1988, 37, 4469-4477. [CrossRef]

19. Cavin, C.; Delatour, T.; Marin-Kuan, M.; Holzhäuser, D.; Higgins, L.; Bezencon, C.; Guignard, G.; Junod, S.; Richoz-Payot, J.; Gremaud, E. Reduction in antioxidant defenses may contribute to ochratoxin A toxicity and carcinogenicity. Toxicol. Sci. 2007, 96, 30-39. [CrossRef]

20. Petrik, J.; Žanić-Grubišić, T.; Barišić, K.; Pepeljnjak, S.; Radić, B.; Ferenčić, Ž.; Čepelak, I. Apoptosis and oxidative stress induced by ochratoxin A in rat kidney. Arch. Toxicol. 2003, 77, 685-693. [CrossRef]

21. Schaaf, G.; Nijmeijer, S.; Maas, R.; Roestenberg, P.; De Groene, E.; Fink-Gremmels, J. The role of oxidative stress in the ochratoxin A-mediated toxicity in proximal tubular cells. Biochim. Biophys. Acta (BBA) Mol. Basis Dis. 2002, 1588, 149-158. [CrossRef]

22. Klaunig, J.E.; Kamendulis, L.M. The role of oxidative stress in carcinogenesis. Annu. Rev. Pharmacol. Toxicol. 2004, 44, 239-267. [CrossRef]

23. Marin-Kuan, M.; Cavin, C.; Delatour, T.; Schilter, B. Ochratoxin A carcinogenicity involves a complex network of epigenetic mechanisms. Toxicon 2008, 52, 195-202. [CrossRef]

24. Czakai, K.; Müller, K.; Mosesso, P.; Pepe, G.; Schulze, M.; Gohla, A.; Patnaik, D.; Dekant, W.; Higgins, J.M.; Mally, A. Perturbation of mitosis through inhibition of histone acetyltransferases: The key to ochratoxin a toxicity and carcinogenicity? Toxicol. Sci. 2011, 122, 317-329. [CrossRef]

25. Hibi, D.; Kijima, A.; Kuroda, K.; Suzuki, Y.; Ishii, Y.; Jin, M.; Nakajima, M.; Sugita-Konishi, Y.; Yanai, T.; Nohmi, T. Molecular mechanisms underlying ochratoxin A-induced genotoxicity: Global gene expression analysis suggests induction of DNA double-strand breaks and cell cycle progression. J. Toxicol. Sci. 2013, 38, 57-69. [CrossRef] [PubMed]

26. Pfohl-Leszkowicz, A.; Manderville, R.A. An update on direct genotoxicity as a molecular mechanism of ochratoxin a carcinogenicity. Chem. Res. Toxicol. 2012, 25, 252-262. [CrossRef]

27. Lee, H.J.; Pyo, M.C.; Shin, H.S.; Ryu, D.; Lee, K.-W. Renal toxicity through AhR, PXR, and Nrf2 signaling pathway activation of ochratoxin A-induced oxidative stress in kidney cells. Food Chem. Toxicol. 2018, 122, 59-68. [CrossRef] [PubMed]

28. Pyo, M.C.; Choi, I.-G.; Lee, K.-W. Transcriptome Analysis Reveals the AhR, Smad2/3, and HIF-1 $\alpha$ Pathways as the Mechanism of Ochratoxin A Toxicity in Kidney Cells. Toxins 2021, 13, 190. [CrossRef]

29. Erikstein, B.S.; Hagland, H.R.; Nikolaisen, J.; Kulawiec, M.; Singh, K.K.; Gjertsen, B.T.; Tronstad, K.J. Cellular stress induced by resazurin leads to autophagy and cell death via production of reactive oxygen species and mitochondrial impairment. J. Cell. Biochem. 2010, 111, 574-584. [CrossRef]

30. Sreemannarayana, O.; Frohlich, A.; Vitti, T.; Marquardt, R.; Abramson, D. Studies of the tolerance and disposition of ochratoxin A in young calves. J. Anim. Sci. 1988, 66, 1703-1711. [CrossRef]

31. Galtier, P.; Alvinerie, M.; Charpenteau, J. The pharmacokinetic profiles of ochratoxin A in pigs, rabbits and chickens. Food Cosmet. Toxicol. 1981, 19, 735-738. [CrossRef]

32. Studer-Rohr, I.; Schlatter, J.; Dietrich, D.R. Kinetic parameters and intraindividual fluctuations of ochratoxin A plasma levels in humans. Arch. Toxicol. 2000, 74, 499-510. [CrossRef] [PubMed]

33. Authority, E.F.S. Opinion of the Scientific Panel on contaminants in the food chain [CONTAM] related to ochratoxin A in food. EFSA J. 2006, 4, 365. [CrossRef]

34. Chu, F.S. Interaction of ochratoxin A with bovine serum albumin. Arch. Biochem. Biophys. 1971, 147, 359-366. [CrossRef]

35. Bondy, G.; Armstrong, C. Cytotoxicity of nephrotoxic fungal toxins to kidney-derived LLC-PK 1 and OK cell lines. Cell Biol. Toxicol. 1998, 14, 323-332. [CrossRef] [PubMed]

36. Özcan, Z.; Gül, G.; Yaman, I. Ochratoxin A activates opposing c-MET/PI3K/Akt and MAPK/ERK 1-2 pathways in human proximal tubule HK-2 cells. Arch. Toxicol. 2015, 89, 1313-1327. [CrossRef] [PubMed]

37. Boesch-Saadatmandi, C.; Loboda, A.; Józkowicz, A.; Huebbe, P.; Blank, R.; Wolffram, S.; Dulak, J.; Rimbach, G. Effect of ochratoxin A on redox-regulated transcription factors, antioxidant enzymes and glutathione-S-transferase in cultured kidney tubulus cells. Food Chem. Toxicol. 2008, 46, 2665-2671. [CrossRef] [PubMed]

38. Dietrich, D.R.; O’Brien, E.; Stack, M.E.; Heussner, A.H. Species-and sex-specific renal cytotoxicity of ochratoxin A and B in vitro. Exp. Toxicol. Pathol. 2001, 53, 215-225. [CrossRef]

39. Arbillaga, L.; Azqueta, A.; van Delft, J.H.; de Cerain, A.L. In vitro gene expression data supporting a DNA non-reactive genotoxic mechanism for ochratoxin A. Toxicol. Appl. Pharmacol. 2007, 220, 216-224. [CrossRef]

40. Hadjeba-Medjdoub, K.; Tozlovanu, M.; Pfohl-Leszkowicz, A.; Frenette, C.; Paugh, R.J.; Manderville, R.A. Structure-activity relationships imply different mechanisms of action for Ochratoxin A-mediated cytotoxicity and genotoxicity. Chem. Res. Toxicol. 2012, 25, 181-190. [CrossRef]

41. Pfohl-Leszkowicz, A.; Tozlovanu, M.; Manderville, R.; Peraica, M.; Castegnaro, M.; Stefanovic, V. New molecular and field evidences for the implication of mycotoxins but not aristolochic acid in human nephropathy and urinary tract tumor. Mol. Nutr. Food Res. 2007, 51, 1131-1146. [CrossRef]

42. Baldi, A.; Losio, M.; Cheli, F.; Rebucci, R.; Sangalli, L.; Fusi, E.; Bertasi, B.; Pavoni, E.; Carli, S.; Politis, I. Evaluation of the protective effects of $\alpha$-tocopherol and retinol against ochratoxin A cytotoxicity. Br. J. Nutr. 2004, 91, 507-512. [CrossRef] [PubMed] 
43. Costa, S.; Utan, A.; Cervellati, R.; Speroni, E.; Guerra, M. Catechins: Natural free-radical scavengers against ochratoxin A-induced cell damage in a pig kidney cell line (LLC-PK1). Food Chem. Toxicol. 2007, 45, 1910-1917. [CrossRef]

44. Arbillaga, L.; Azqueta, A.; Ezpeleta, O.; Cerain, A.L.d. Oxidative DNA damage induced by ochratoxin A in the HK-2 human kidney cell line: Evidence of the relationship with cytotoxicity. Mutagenesis 2007, 22, 35-42. [CrossRef] [PubMed]

45. McCarthy, D.J.; Smyth, G.K. Testing significance relative to a fold-change threshold is a TREAT. Bioinformatics 2009, 25, 765-771. [CrossRef]

46. Lushchak, V.I. Free radicals, reactive oxygen species, oxidative stress and its classification. Chem. Biol. Interact. 2014, 224, 164-175. [CrossRef]

47. National Institutes of Health (NTP). National Toxicology Program Chemical Repository Database; NTP: Research Triangle Park, NC, USA, 1992. Available online: https:/ /ntp.niehs.nih.gov/go/tr358 (accessed on 11 May 2021).

48. United States Environmental Protection Agency (US EPA). Estimation Program Interface (EPI) Suite. Ver. 4.1. 2012. Available online: https: / / www.epa.gov/tsca-screening-tools/download-epi-suitetm-estimation-program-interface-v411 (accessed on 11 May 2021).

49. O'Brien, E.; Heussner, A.H.; Dietrich, D.R. Species-, sex-, and cell type-specific effects of ochratoxin A and B. Toxicol. Sci. 2001, 63, 256-264. [CrossRef] [PubMed]

50. Jennings, P.; Weiland, C.; Limonciel, A.; Bloch, K.M.; Radford, R.; Aschauer, L.; McMorrow, T.; Wilmes, A.; Pfaller, W.; Ahr, H.J. Transcriptomic alterations induced by Ochratoxin $\mathrm{A}$ in rat and human renal proximal tubular in vitro models and comparison to a rat in vivo model. Arch. Toxicol. 2012, 86, 571-589. [CrossRef]

51. Brandsch, M.; Ganapathy, V.; Leibach, F.H. H (+)-peptide cotransport in Madin-Darby canine kidney cells: Expression and calmodulin-dependent regulation. Am. J. Physiol. Ren. Physiol. 1995, 268, F391-F397. [CrossRef]

52. Schwerdt, G.; Freudinger, R.; Silbernagl, S.; Gekle, M. Apical uptake of radiolabelled ochratoxin A into Madin-Darby canine kidney cells. Toxicology 1998, 131, 193-202. [CrossRef]

53. Schwerdt, G.; Gekle, M.; Freudinger, R.; Mildenberger, S.; Silbernagl, S. Apical-to-basolateral transepithelial transport of ochratoxin A by two subtypes of Madin-Darby canine kidney cells. Biochim. Biophys. Acta (BBA) Biomembr. 1997, 1324, 191-199. [CrossRef]

54. Dürst, M.; Dzarlieva-Petrusevska, R.; Boukamp, P.; Fusenig, N.; Gissmann, L. Molecular and cytogenetic analysis of immortalized human primary keratinocytes obtained after transfection with human papillomavirus type 16 DNA. Oncogene 1987, 1, $251-256$.

55. Halbert, C.; Demers, G.; Galloway, D. The E7 gene of human papillomavirus type 16 is sufficient for immortalization of human epithelial cells. J. Virol. 1991, 65, 473-478. [CrossRef]

56. Hawley-Nelson, P.; Vousden, K.H.; Hubbert, N.L.; Lowy, D.R.; Schiller, J.T. HPV16 E6 and E7 proteins cooperate to immortalize human foreskin keratinocytes. EMBO J. 1989, 8, 3905-3910. [CrossRef]

57. Howley, P.M. Role of the human papillomaviruses in human cancer. Cancer Res. 1991, 51, 5019s-5022s. [PubMed]

58. Pirisi, L.; Creek, K.E.; Doniger, J.; Dipaolo, J.A. Continuous cell lines with altered growth and differentiation properties originate after transfection of human keratinocytes with human papillomavirus type 16 DNA. Carcinogenesis 1988, 9, 1573-1579. [CrossRef] [PubMed]

59. Pirisi, L.; Yasumoto, S.; Feller, M.; Doniger, J.; DiPAOLO, J.A. Transformation of human fibroblasts and keratinocytes with human papillomavirus type 16 DNA. J. Virol. 1987, 61, 1061-1066. [CrossRef]

60. Chang, S.E. In vitro transformation of human epithelial cells. Biochim. Biophys. Acta (BBA) Rev. Cancer 1986, 823, 161-194. [CrossRef]

61. Graham, F.L.; Smiley, J.; Russell, W.; Nairn, R. Characteristics of a human cell line transformed by DNA from human adenovirus type 5. J. Gen. Virol. 1977, 36, 59-72. [CrossRef] [PubMed]

62. Nanus, D.; Lynch, S.; Rao, P.; Anderson, S.; Jhanwar, S.; Albino, A. Transformation of human kidney proximal tubule cells by a src-containing retrovirus. Oncogene 1991, 6, 2105-2111.

63. Robinson, P.S.; Goochee, C.F. Kidney-specific enzyme expression by human kidney cell lines generated through oncogene transfection. J. Cell. Physiol. 1991, 148, 54-59. [CrossRef] [PubMed]

64. Schwerdt, G.; Bauer, K.; Gekle, M.; Silbernagl, S. Accumulation of ochratoxin A in rat kidney in vivo and in cultivated renal epithelial cells in vitro. Toxicology 1996, 114, 177-185. [CrossRef]

65. Schwerdt, G.; Freudinger, R.; Silbernagl, S.; Gekle, M. Ochratoxin A-binding proteins in rat organs and plasma and in different cell lines of the kidney. Toxicology 1999, 135, 1-10. [CrossRef]

66. Heussner, A.H.; O’Brien, E.; Dietrich, D.R. Species-and sex-specific variations in binding of ochratoxin A by renal proteins in vitro. Exp. Toxicol. Pathol. 2002, 54, 151-159. [CrossRef]

67. Galtier, P.; Charpenteau, J.-L.; Alvinerie, M.; Labouche, C. The pharmacokinetic profile of ochratoxin A in the rat after oral and intravenous administration. Drug Metab. Dispos. 1979, 7, 429-434. [PubMed]

68. Hagelberg, S.; Hult, K.; Fuchs, R. Toxicokinetics of ochratoxin A in several species and its plasma-binding properties. J. Appl. Toxicol. 1989, 9, 91-96. [CrossRef] [PubMed]

69. Schieber, M.; Chandel, N.S. ROS function in redox signaling and oxidative stress. Curr. Biol. 2014, 24, R453-R462. [CrossRef] [PubMed]

70. Karlsson, M.; Kurz, T.; Brunk, U.T.; Nilsson, S.E.; Frennesson, C.I. What does the commonly used DCF test for oxidative stress really show? Biochem. J. 2010, 428, 183-190. [CrossRef] 
71. Schwerdt, G.; Freudinger, R.; Mildenberger, S.; Silbernagl, S.; Gekle, M. The nephrotoxin ochratoxin A induces apoptosis in cultured human proximal tubule cells. Cell Biol. Toxicol. 1999, 15, 405-415. [CrossRef] [PubMed]

72. Klarić, M.Š.; Rumora, L.; Ljubanović, D.; Pepeljnjak, S. Cytotoxicity and apoptosis induced by fumonisin B 1, beauvericin and ochratoxin A in porcine kidney PK15 cells: Effects of individual and combined treatment. Arch. Toxicol. 2008, 82, 247-255. [CrossRef] [PubMed]

73. Barišić, K.; Rumora, L.; Petrik, J.; Čepelak, I.; Žanić-Grubišić, T. Ochratoxin A induces apoptosis in LLC-PK1 cells via JNK and p38 MAPK activation. Croat. Chem. Acta 2005, 78, 385-392.

74. Liang, R.; Shen, X.L.; Zhang, B.; Li, Y.; Xu, W.; Zhao, C.; Luo, Y.; Huang, K. Apoptosis signal-regulating kinase 1 promotes Ochratoxin A-induced renal cytotoxicity. Sci. Rep. 2015, 5, 8078. [CrossRef] [PubMed]

75. Yang, Q.; Shi, L.; Huang, K.; Xu, W. Protective effect of N-acetylcysteine against DNA damage and S-phase arrest induced by ochratoxin A in human embryonic kidney cells (HEK-293). Food Chem. Toxicol. 2014, 70, 40-47. [CrossRef]

76. Bhattacharya, S.; Gachhui, R.; Sil, P.C. Hepatoprotective properties of kombucha tea against TBHP-induced oxidative stress via suppression of mitochondria dependent apoptosis. Pathophysiology 2011, 18, 221-234. [CrossRef]

77. Sarkar, M.K.; Sil, P.C. Prevention of tertiary butyl hydroperoxide induced oxidative impairment and cell death by a novel antioxidant protein molecule isolated from the herb, Phyllanthus niruri. Toxicol. In Vitro 2010, 24, 1711-1719. [CrossRef]

78. Zavodnik, L.B.; Zavodnik, I.B.; Niekurzak, A.; Szosland, K.; Bryszewska, M. Activation of red blood cell glutathione peroxidase and morphological transformation of erythrocytes under the action of tert-butyl hydroperoxide. IUBMB Life 1998, 44, 577-588. [CrossRef] [PubMed]

79. Benatti, U.; Morelli, A.; Damiani, G.; De Flora, A. A methemoglobin-dependent and plasma-stimulated experimental model of oxidative hemolysis. Biochem. Biophys. Res. Commun. 1982, 106, 1183-1190. [CrossRef]

80. Deuticke, B.; Heller, K.B.; Haest, C.W. Progressive oxidative membrane damage in erythrocytes after pulse treatment with t-butylhydroperoxide. Biochim. Biophys. Acta (BBA) Biomembr. 1987, 889, 113-124. [CrossRef]

81. Yu, S.-W.; Wang, H.; Poitras, M.F.; Coombs, C.; Bowers, W.J.; Federoff, H.J.; Poirier, G.G.; Dawson, T.M.; Dawson, V.L. Mediation of poly (ADP-ribose) polymerase-1-dependent cell death by apoptosis-inducing factor. Science 2002, 297, 259-263. [CrossRef]

82. Espinosa-Diez, C.; Miguel, V.; Mennerich, D.; Kietzmann, T.; Sánchez-Pérez, P.; Cadenas, S.; Lamas, S. Antioxidant responses and cellular adjustments to oxidative stress. Redox Biol. 2015, 6, 183-197. [CrossRef]

83. Klarić, M.Š.; Medić, N.; Hulina, A.; Grubišić, T.Ž.; Rumora, L. Disturbed Hsp70 and Hsp27 expression and thiol redox status in porcine kidney PK15 cells provoked by individual and combined ochratoxin A and citrinin treatments. Food Chem. Toxicol. 2014, 71, 97-105. [CrossRef]

84. Raghubeer, S.; Nagiah, S.; Phulukdaree, A.; Chuturgoon, A. The phytoalexin resveratrol ameliorates ochratoxin A toxicity in human embryonic kidney (HEK293) cells. J. Cell. Biochem. 2015, 116, 2947-2955. [CrossRef] [PubMed]

85. Zhang, J.; Cao, M.; Yang, W.; Sun, F.; Xu, C.; Yin, L.; Pu, Y. Inhibition of glucose-6-phosphate dehydrogenase could enhance 1, 4-benzoquinone-induced oxidative damage in K562 cells. Oxid. Med. Cell. Longev. 2016, 2016, 3912515. [CrossRef] [PubMed]

86. Stanton, R.C. Glucose-6-phosphate dehydrogenase, NADPH, and cell survival. IUBMB Life 2012, 64, 362-369. [CrossRef]

87. Li, J.; Yin, S.; Dong, Y.; Fan, L.; Hu, H. p53 activation inhibits ochratoxin A-induced apoptosis in monkey and human kidney epithelial cells via suppression of JNK activation. Biochem. Biophys. Res. Commun. 2011, 411, 458-463. [CrossRef]

88. Gan, F.; Xue, H.; Huang, Y.; Pan, C.; Huang, K. Selenium alleviates porcine nephrotoxicity of ochratoxin A by improving selenoenzyme expression in vitro. PLoS ONE 2015, 10, e0119808. [CrossRef]

89. Roussel, A.M.; Favier, A.; Anderson, R. Trace Elements in Man and Animals 10; Springer Science \& Business Media: Berlin/Heidelberg, Germany, 2006.

90. Riss, T.; Moravec, R.; Niles, A.; Duellman, S.; Benink, H.; Worzella, T.; Minor, L. Cell Viability Assays. In Assay Guidance Manual [Internet]; Eli Lilly \& Company and the National Center for Advancing Translational Sciences: Bethesda, MD, USA, 2004.

91. Wang, H.; Joseph, J.A. Quantifying cellular oxidative stress by dichlorofluorescein assay using microplate reader. Free Radic. Biol. Med. 1999, 27, 612-616. [CrossRef]

92. Ellman, G.L. Tissue sulfhydryl groups. Arch. Biochem. Biophys. 1959, 82, 70-77. [CrossRef]

93. Schmittgen, T.D.; Livak, K.J. Analyzing real-time PCR data by the comparative $\mathrm{C}_{\mathrm{T}}$ method. Nat. Protoc. 2008, 3, 1101. [CrossRef] [PubMed] 